\title{
QUALITY ASSESSMENT OF EGGS PACKED UNDER MODIFIED ATMOSPHERE
}

\author{
Avaliação da qualidade de ovos embalados sob atmosfera modificada
}

\author{
Aline Giampietro-Ganeco' ${ }^{1}$, Hirasilva Borba ${ }^{2}$, Aline Mary Scatolini-Silva ${ }^{2}$, \\ Marcel Manente Boiago ${ }^{3}$, Pedro Alves de Souza ${ }^{2}$, Juliana Lolli Malagoli de Mello²
}

\begin{abstract}
Eggs are perishable foods and lose quality quickly if not stored properly. From the moment of posture to the marketing of egg, quality loss occurs through gas exchange and water through the pores of the shell with the external environment and thus, studies involving modified atmosphere packaging are extremely important. The aim of the present study is to assess the internal quality of eggs packed under modified atmosphere and stored at room temperature. Six hundred and twelve fresh commercial eggs from 38-week old Hisex White laying hens were used. The present study was conducted in a completely randomized experimental design in a $4 \times 4+1$ factorial arrangement [vacuum, vacuum with oxygen gas $\left(\mathrm{O}_{2}\right)$ absorbent, vacuum with oxygen gas $\left(\mathrm{O}_{2}\right)$ and carbon dioxide $\left(\mathrm{CO}_{2}\right)$ absorbents, vacuum with oxygen gas $\left(\mathrm{O}_{2}\right)$ absorbent and carbon dioxide $\left(\mathrm{CO}_{2}\right)$ gas generator; storage times (7, 14, 21 and 28 days), control group (fresh eggs)], with three repetitions (12 eggs each). The following factors were assessed: weight maintenance during storage; Haugh unit; color and yolk index. The modified atmosphere packaging maintained the weight of the eggs during a period of 28 days. Vacuum packaging with $\mathrm{O}_{2}$ absorbent and $\mathrm{CO}_{2}$ gas generator was more efficient in maintenance of egg quality, based on the values of Haugh unit and yolk index. The luminosity of the yolk was preserved during the 28 storage days in all of the packaging types used. The vacuum packaging with $\mathrm{O}_{2}$ gas absorbent and $\mathrm{CO}_{2}$ gas generator provide an increase in internal egg quality.
\end{abstract}

Index terms: Storage, sachet, vacuum.

\section{RESUMO}

Os ovos são alimentos perecíveis e perdem sua qualidade rapidamente se não forem armazenados corretamente. Do momento da postura até a comercialização do ovo, ocorre perda de qualidade por meio de trocas gasosas e de água, através dos poros da casca com o ambiente externo, sendo de extrema importância os estudos que envolvam embalagens com atmosfera modificada. O estudo foi realizado com o objetivo de avaliar a qualidade interna de ovos embalados com atmosfera modificada e armazenados em temperatura ambiente. Foram armazenados 612 ovos frescos comerciais de galinhas da linhagem Hisex Branca (HSB) com 38 semanas de idade. Utilizou-se um DIC em esquema fatorial 4x4+1 [vácuo, vácuo com sequestrador de gás oxigênio $\left(\mathrm{O}_{2}\right)$, vácuo com sequestrador de gás oxigênio $\left(\mathrm{O}_{2}\right)$ e de gás carbônico $\left(\mathrm{CO}_{2}\right)$, vácuo com sequestrador de gás oxigênio $\left(\mathrm{O}_{2}\right)$ e gerador de gás carbônico $\left(\mathrm{CO}_{2}\right)$ e períodos de armazenamento 7, 14, 21 e 28 dias + testemunha - ovos frescos], com 3 repetições de 12 ovos cada. As características avaliadas foram: manutenção de peso durante armazenamento, unidade Haugh, índice gema e coloração da gema. As embalagens com atmosfera modificada mantiveram os pesos dos ovos por um período de 28 dias e a embalagem 4 (vácuo com sequestrante de $\mathrm{O}_{2}$ e geradores de $\mathrm{CO}_{2}$ ) foi a que apresentou melhores valores para a unidade Haugh e para o índice gema. A gema preservou sua luminosidade durante os 28 dias de armazenamento, independente da embalagem utilizada. O vácuo das embalagens avaliadas proporcionou efeito positivo na qualidade interna dos ovos e estes, quando armazenados em estojos que continham sequestrador de gás oxigênio $\left(\mathrm{O}_{2}\right)$ e gerador de gás carbônico $\left(\mathrm{CO}_{2}\right)$, preservaram ainda mais a qualidade de suas características internas.

Termos para indexação: Armazenamento, sachês, vácuo.

\section{INTRODUCTION}

The poultry industry has been highlighted due to its ability to produce food of high quality and low cost, thereby providing the poor population with access to high quality animal protein. This success is due to the high standard of development acquired over the years, in all segments of the productive chain including genetics, health, management and nutrition.

Eggs are one of the most nutritionally complete foods due to the excellent balance between fats, carbohydrates, minerals, vitamins and especially protein. Thus, they are considered the second best source of protein available for human consumption,

\footnotetext{
${ }^{1}$ Universidade Estadual Paulista "Júlio de Mesquita Filho"/UNESP - Faculdade de Ciências Agrárias e Veterinárias de Jaboticabal - Departamento de Tecnologia - Via de Acesso Prof. Paulo Donato Castellane - s/n - Zona Rural - 14884-900 - Jaboticabal - SP - Brasil - algiamp@yahoo.com.br ¿Universidade Estadual Paulista "Júlio de Mesquita Filho"/UNESP - Departamento de Tecnologia - Jaboticabal - SP - Brasil

3Universidade do Estado de Santa Catarina/UDESC - Chapecó - SC - Brasil

Received in june 24, 2014 and approved in september 29, 2014
}

Ciênc. Agrotec., Lavras, v.39, n.1, p.82-88, jan./fev., 2015 
preceded only by maternal milk. However, eggs are also an ideal source for the growth of pathogenic microorganisms and, being a product of animal origin, they are highly perishable and can lose their quality rapidly (Theron et al., 2003).

After oviposition, eggs inevitably begin to undergo structural changes which can lead to a loss of quality and eventually deterioration. Although they cannot be completely avoided, these alterations can be retarded by managing storage conditions.

Among the marketing strategies adopted by the egg industry, packaging is very important in terms of consumer choice and conservation of the egg quality. Because the egg is a natural product, differentiation between egg producers based only on appearance is not possible. Packaging plays an important role in this differentiation, conditioning the consumer to particular trademarks. As a result, several companies have invested in upgrading their packaging to maintain egg quality and to appear more practical and attractive to consumers (Antunes, 2001).

Egg quality has different approaches according to the sector supply chain (production, consumer and processing). For producers, quality is related to the weight of the egg, shell strength, deformities, dirt, breakage and blood stains. For consumers, quality is related to the expiration date, sensory properties (color of the yolk and the shell) as well as the nutritional composition (cholesterol, vitamins, fatty acids). For the processing industry, quality is related to the ease of removing the shell, separation of yolk and albumen, functional properties and yolk color (especially in bakery products) (Franco; Sakamoto, 2007).

Although the eggs shell provides an excellent natural protection, it is not sufficient to resist transportation to the market. Losses due to shell damage represent one of the main costs in the marketing of eggs. Therefore, packaging is used as a means of protection for all market eggs (Ogden et al., 2005).

Nowadays, an assessment of the internal quality attributes of eggs associated with the storage form is indispensable. This assessment includes measurements of the albumen and yolk, because eggs with abundant and dense albumen and a centralized yolk give a good impression to the consumer. Become the importance of studies with ways of eggs stored, seek to preserve the attributes mentioned, to ensure internal egg quality. The aim of the present study is to assess the internal quality of eggs packed under modified atmosphere and stored at room temperature.

\section{MATERIAL AND METHODS}

Six hundred and twelve commercial fresh white shell eggs were used. The eggs were classified as large, sanitized and without cracks, and came from 38-week old Hisex White hens, kept under the same rearing system.

The eggs were placed into plastic egg cases (capacity of 12) with the following measurements: 29 $\mathrm{cm}$ length, $10 \mathrm{~cm}$ width and $6 \mathrm{~cm}$ height. The plastic egg cases were packaged in Protervac ${ }^{\circledR}$ plastic bags with thickness $0.1 \mathrm{~mm}$, porosity $<85 \mathrm{O}_{2} \mathrm{cc} / \mathrm{m}^{2}$ in 24 hours at $23^{\circ} \mathrm{C}$. The plastic bags with $20 \mathrm{~cm}$ width, $51 \mathrm{~cm}$ length and $180 \mu$ thick were sealed under vacuum using the Selovac ${ }^{\circledR} 200$ B. Four different conditions of modified atmosphere were used: 1- vacuum; 2- vacuum with oxygen gas $\left(\mathrm{O}_{2}\right)$ absorbent; 3 - vacuum with oxygen gas $\left(\mathrm{O}_{2}\right)$ and carbon dioxide $\left(\mathrm{CO}_{2}\right)$ absorbents; and 4- vacuum with oxygen gas $\left(\mathrm{O}_{2}\right)$ absorbent and carbon dioxide $\left(\mathrm{CO}_{2}\right)$ gas generator.

Absorption or gas generation in packaging was obtained using $\mathrm{O}_{2}$ and/or $\mathrm{CO}_{2}$ absorbent/generation sachets. Each all sachet was able to absorb $50 \mathrm{cc}$ of gas. According to the dimensions of the package used, two sachets were added to each, following the manufacturer's instructions.

The sequestering $\mathrm{O}_{2}$ sachets are produced by a chemical powder based iron, activated carbon, salt and calcium carbonate. The absorbent of $\mathrm{O}_{2}$ and $\mathrm{CO}_{2}$ by iron, activated carbon, salt, calcium carbonate and diatomite and absorbent of $\mathrm{O}_{2}$ and $\mathrm{CO}_{2}$ generation by ascorbic acid, activated carbon, salt and calcium carbonate.

The eggs were then stored for 28 days at room temperature (ranging from 23.4 to $30.3^{\circ} \mathrm{C}$ ) and $41-70 \%$ relative humidity $(\mathrm{RH})$. All analyses were conducted with fresh eggs (control group - analyzed on the day of egg laying), and with eggs after storage in 7, 14, 21 and 28 days.

A completely randomized experimental design in a $4 \times 4+1$ factorial arrangement with types of package (plastic eggs cases) against storage days $(7,14,21$ and 28 days) and control group was used in three replicates plastic eggs cases of twelve eggs each. The results were submitted to analysis of variance (ANOVA) using the GLM Procedure of SAS ${ }^{\text {ò }}$ software. The differences between the means were compared using Tukey's test with the significance level at 5\%.

At each storage period, including day 0 when the control group was analyzed, three cases different of each treatment were separated and four eggs from each plastics 
eggs case were assessed in all terms of maintenance of weight during storage, albumen and yolk quality, and yolk color.

The maintenance of weight during storage was assessed by weighing eggs before and after each storage period. The difference between the initial and final weight was used to calculate the percentage of the maintenance of weight.

Albumen quality was assessed by the Haugh unit method (Haugh, 1937), as described by Card and Nesheim (1978). After weighing, the eggs were broken on a glass table and the albumen height mensurated using an Egg Quality Micrometer. The Haugh unit was calculated using the following formula:

Haugh Unit $=100 \log \left(\mathrm{H}+7.57-1.7 \mathrm{~W}^{0.37}\right)$.

where, $\mathrm{H}=$ Albumen height (in $\mathrm{mm}$ ), $\mathrm{W}=$ Weight of the egg (in $g$ ).

Egg yolk quality was assessed using the yolk index, represented by the ratio between height $(\mathrm{mm})$ and diameter $(\mathrm{mm})$ of the yolk (Yolk Index = yolk height $/$ yolk diameter), mensurated with the Egg Quality Micrometer and digital caliper $(0-150 \mathrm{~mm})$, respectively. The yolk color was recorded with the Minolta Chroma Meter by assessing the $L^{*} a^{*} b^{*}$ color space $(L=$ lightness, $a=$ redness, $b=$ yellowness).

\section{RESULTS AND DISCUSSION}

Table 1 displays the interaction between storage time and packaging under different vacuum conditions using Haugh units (HU) and Yolk index (YI). Table 2 displays the HU and YI values for each packaging system in relation to each storage time.

The modified atmosphere packaging maintained the weight of the eggs during a period of 28 days. No statistically significant difference $(\mathrm{P}<0.05)$ was found between control (fresh eggs) and experimental groups in terms of egg weight maintenance. The vacuum packaging systems assessed were able to prevent water loss in eggs, and consequently to maintain the eggs weight during the storage period.

The modified atmosphere packaging maintained the weight of the eggs during a period of 28 days. No statistically significant difference $(\mathrm{P}<0.05)$ was found between control (fresh eggs - newly putted and without storaged) and experimental groups (all the storaged packaging under different vacuum) in terms of egg weight maintenance.
This view the vacuum packaging systems assessed were able to prevent water loss in eggs, and consequently to maintain the eggs weight during the storage period. A reduction of weight or the size of the air cell in eggs is due to water loss by evaporation through the shell is a natural process egg. The rate at which the loss of humidity occurs is related to eggshell porosity and environmental conditions and can thus losing quality.

Jones and Musgrove (2005) studied the effects of extended storage on egg quality factors. Eggs from a single inline processing facility were collected weekly for three weeks (replicates). The eggs were stored at $4{ }^{\circ} \mathrm{C}$ and $80 \% \mathrm{RH}$. The egg weights obtained remained fairly constant throughout the storage period for replicates of the study. In the present study, the packings vacuum of eggs at room temperature also maintained the egg weight.

Santos et al. (2009) studied the effects of the temperature of preservation (room temperature and refrigeration) and egg storage time (7, 14 and 21 days), found that the height of dense albumen and yolk index are measures of internal quality related to weight loss. Both albumen and yolk are components of structures involved in water loss, causing decrease in the eggs weight.

In a previous study that analyzed different conditions of egg packaging at room temperature, a lower efficiency was observed when plastic film was utilized as a barrier to prevent egg weight loss stored for 28 days (Scatolini-Silva, 2010). The eggs stored in plastic film exhibited a lower percentage of weight maintenance in relation to eggs that were vacuum packed. These results corroborate the observations of the present study, in which it was also found that storage at vacuum conditions was more effective in maintaining the weight of eggs.

Upon analysis of the interaction between storage time and packing using the HU values (Table 2), it was confirmed that the quality of albumen of packing two and three (vacuum with $\mathrm{O}_{2}$ absorbent and vacuum with $\mathrm{O}_{2}$ and $\mathrm{CO}_{2}$ absorbents, respectively) decreased after 21 days of storage, whereas in packing one, the reduction only occurred after 28 days. This result is not surprising, considering that albumen fluidification occurs at high temperatures, such as those observed in the region of the present study (state of São Paulo, Brazil). In high temperatures, there is an increase in physical and chemical reactions which may cause protein degradation in albumen. On the other hand, packing four (vacuum 
Table 1 - Mean Haugh Units (HU), Yolk Index (YI) and weight maintenance (\%WM) of packed eggs under different vacuum conditions and storage time at room temperature.

\begin{tabular}{|c|c|c|c|}
\hline & $\mathrm{HU}$ & YI & $\% \mathrm{WM}$ \\
\hline \multicolumn{4}{|c|}{ Control vs Factorial } \\
\hline Control & $81.02^{\text {a }}$ & $0.44^{\mathrm{a}}$ & $100.00^{\mathrm{a}}$ \\
\hline \multirow[t]{2}{*}{ Factorial } & $54.17^{\mathrm{b}}$ & $0.34^{\mathrm{b}}$ & $99.28^{\mathrm{a}}$ \\
\hline & $\mathrm{P}<0.01$ & $\mathrm{P}<0.01$ & NS \\
\hline \multicolumn{4}{|c|}{ Storage time in days $(\mathrm{T})$} \\
\hline 7 & 61.72 & 0.38 & $99.75^{a}$ \\
\hline 14 & 58.30 & 0.36 & $98.99^{\mathrm{a}}$ \\
\hline 21 & 47.70 & 0.32 & $98.93^{\mathrm{a}}$ \\
\hline \multirow[t]{3}{*}{28} & 48.95 & 0.32 & $99.43^{\mathrm{a}}$ \\
\hline & $\mathrm{P}<0.01$ & $\mathrm{P}<0.01$ & NS \\
\hline & \multicolumn{3}{|c|}{ Packing $(\mathrm{P})$} \\
\hline 1 - vacuum & & 0.35 & $99.61^{\mathrm{a}}$ \\
\hline 2 - seq. $\mathrm{O}_{2}$ & & 0.31 & $99.71^{\mathrm{a}}$ \\
\hline 3 - seq. $\mathrm{O}_{2} / \mathrm{CO}_{2}$ & & 0.30 & $99.63^{\mathrm{a}}$ \\
\hline \multirow[t]{2}{*}{$4-$ seq. $\mathrm{O}_{2} /$ ger. $\mathrm{CO}_{2}$} & & 0.42 & $98.15^{\mathrm{a}}$ \\
\hline & $\mathrm{P}<0.01$ & $\mathrm{P}<0.01$ & $\mathrm{P}<0.05$ \\
\hline Int. TxP & $\mathrm{P}<0.01$ & $\mathrm{P}<0.01$ & NS \\
\hline $\mathrm{CV}(\%)$ & 7.97 & 3.53 & 1.56 \\
\hline
\end{tabular}

Means followed by the same letter at the column do not differ by Tukey test $(\mathrm{P}<0.05) ; \mathrm{CV}=$ coefficient of variation; NS $=$ nonsignificant. $\mathrm{O}_{2}=$ oxygen; $\mathrm{CO}_{2}=$ carbon dioxide.

Table 2 - Haugh Unit (HU) and Yolk Index (YI) to each vacuum packaging system at different storage time.

\begin{tabular}{|c|c|c|c|c|}
\hline \multirow{2}{*}{ Packing $(\mathrm{P})$} & \multicolumn{4}{|c|}{ Storage time in days $(\mathrm{T})-\mathrm{HU}$} \\
\hline & 7 & 14 & 21 & 28 \\
\hline 1 - vacuum & $54.47^{\mathrm{bx}}$ & $59.79^{\mathrm{a}, \mathrm{bx}}$ & $51.35^{\mathrm{bx}}$ & $47.29^{\text {by }}$ \\
\hline $2-$ seq. $\mathrm{O}_{2}$ & $56.39^{\mathrm{bx}}$ & $54.06^{b x}$ & $39.49^{\text {by }}$ & $36.49^{\text {by }}$ \\
\hline $3-$ seq. $\mathrm{O}_{2} / \mathrm{CO}_{2}$ & $55.23^{b x}$ & $50.49^{\text {bx }}$ & $27.47^{\mathrm{cy}}$ & $43.59^{\text {by }}$ \\
\hline 4 - seq. $\mathrm{O}_{2}$ /ger. $\mathrm{CO}_{2}$ & $80.80^{\text {ax }}$ & $68.88^{\mathrm{ax}}$ & $72.50^{\mathrm{ax}}$ & $68.43^{\text {ay }}$ \\
\hline \multirow{2}{*}{ Packing (P) } & \multicolumn{4}{|c|}{ Storage time in days $(\mathrm{T})-\mathrm{YI}$} \\
\hline & 7 & 14 & 21 & 28 \\
\hline $1-$ vacuum & $0.38^{\mathrm{bx}}$ & $0.36^{\text {by }}$ & $0.32^{\mathrm{bz}}$ & $0.32^{\mathrm{bz}}$ \\
\hline $2-$ seq. $\mathrm{O}_{2}$ & $0.34^{\mathrm{bx}}$ & $0.34^{\text {by }}$ & $0.28^{\text {by }}$ & $0.28^{\text {by }}$ \\
\hline 3 - seq. $\mathrm{O}_{2} / \mathrm{CO}_{2}$ & $0.35^{\mathrm{bx}}$ & $0.31^{\text {by }}$ & $0.26^{\mathrm{bz}}$ & $0.27^{\mathrm{bz}}$ \\
\hline $4-$ seq. $\mathrm{O}_{2} /$ ger. $\mathrm{CO}_{2}$ & $0.45^{\mathrm{ax}}$ & $0.43^{\mathrm{ax}}$ & $0.41^{\mathrm{ax}}$ & $0.41^{\mathrm{ax}}$ \\
\hline
\end{tabular}

a,bMeans followed by the same letter (column) do not differ by Tukey test $(\mathrm{P}<0.05)$; ${ }^{x, y, z}$ Means followed by the same letter (line) do not differ by Tukey test $(\mathrm{P}<0.05) ; \mathrm{O}_{2}=$ oxygen; $\mathrm{CO}_{2}=$ carbon dioxide. 
with $\mathrm{O}_{2}$ absorbent and $\mathrm{CO}_{2}$ gas generator) preserved the quality of albumen for the 28 days of storage, as confirmed by the HU.

The Quality Control Program of the United States Department of Agriculture (USDA) determines quality conditions of eggs that will be consumed. According to this classification, eggs may be classified as follows: eggs of excellent quality (AA) are those that exhibit $\mathrm{HU}$ values of 72 or higher; eggs of high quality (A) are those with HU values between 60 and 72; and eggs of low quality are those with HU values lower than 60 (USDA, 2000). In the present study the maximum storage time used was 28 days and at this time, packing four (vacuum with $\mathrm{O}_{2}$ absorbent and $\mathrm{CO}_{2}$ gas generator) was able to preserve the quality of albumen at the "A" level of classification. In the same storage time, the other packing systems were unable to maintain the quality of eggs (classification "B").

Karoui, Nicolaï and Baerdemaeker (2008) studied egg freshness during storage in a modified atmosphere using fluorescence spectroscopy. After 6 days of storage, the authors found that the HU values in eggs maintained in $4.6 \%$ of $\mathrm{CO}_{2}$ were $7.7 \%$ higher than eggs stored in $2 \%$ of $\mathrm{CO}_{2}$. After 22 days, this difference increased to $16 \%$, and at the end of the storage period (after 47 days), the HU difference was $21 \%$. The decrease in HU values was associated with a reduction in egg quality. Despite the reduction in the egg quality, the study showed that eggs stored at $12.2{ }^{\circ} \mathrm{C}$ and $87 \% \mathrm{RH}$ in an atmosphere containing 2 or $4.6 \%$ of $\mathrm{CO}_{2}$ maintained their AA grading (according to USDA standards, $\mathrm{HU}>72$ ) until the end of the experiment, the same study found that packaging containing $\mathrm{CO}_{2}$ to 21 days of storage (HU 72.50).

Regarding the yolk quality, packing four also proved to be more effective during the storage period used.
The YI mean values showed no significant differences $(\mathrm{P}>0.05)$ in comparison to the values found with fresh eggs, which ranged from 0.42 to 0.40 . After only seven days of storage, this was not true for the other packing systems $(1,2,3)$.

Similar to the results of the present study, Leandro et al. (2005) found that the reduction in quality of eggs is mainly associated with water and $\mathrm{CO}_{2}$ loss during storage, and is proportional to an increase in the room temperature. There is an increase in physical and chemical reactions that may cause protein degradation in dense albumen, as a result of water linked to large protein molecules passing through to the yolk by osmosis.

Table 3 displays the interaction between storage time and packing systems using the redness $\left(a^{*}\right)$ and yellowness ( $\left.b^{*}\right)$ of the yolk. Table 4 displays the $a^{*}$ and $b^{*}$ values for each packaging system at each storage time. No significant differences $(\mathrm{P}<0.05)$ were detected between experimental and control egg groups for luminosity $\left(\mathrm{L}^{*}\right)$ (Table 3), indicating that the yolk quality was preserved during the 28 days of storage, regardless of the packing utilized.

Freitas et al. (2011) studied the effects of temperature and storage time on egg quality and found similar values to those of the present study for yolk luminosity (67.44) of eggs stored at refrigeration temperature for 21 days.

Upon analysis of the data presented in table 4, it was confirmed that the redness $\left(a^{*}\right)$ had not changed during the 28 days in packing three (vacuum with $\mathrm{O}_{2}$ and $\mathrm{CO}_{2}$ absorbent). The same was not found in the three other packings, which were unstable for this factor. No differences were found between the storage systems in terms of yellowness ( $b^{*}$ ) after 21 days of storage. However, this was not true after 28 days. Therefore, the vacuum was not effective to preserve the intensity of color. 
Table 3 - Mean luminosity $\left(\mathrm{L}^{*}\right)$, redness $\left(\mathrm{a}^{*}\right)$ and yellowness $\left(\mathrm{b}^{*}\right)$ of packed eggs under different vacuum conditions and storage time at room temperature.

\begin{tabular}{|c|c|c|c|}
\hline & $\mathrm{L}^{*}$ & $\mathrm{a}^{*}$ & $b^{*}$ \\
\hline \multicolumn{4}{|c|}{ Control vs Factorial } \\
\hline Control & $64.92^{a}$ & $5.97^{\text {a }}$ & $38.60^{\mathrm{b}}$ \\
\hline \multirow[t]{2}{*}{ Factorial } & $61.16^{\mathrm{a}}$ & $5.68^{b}$ & $44.39^{\mathrm{a}}$ \\
\hline & NS & $\mathrm{P}<0.05$ & $\mathrm{P}<0.01$ \\
\hline \multicolumn{4}{|c|}{ Storage time in days $(\mathrm{T})$} \\
\hline 7 & $65.66^{\mathrm{a}}$ & 5.74 & 40.79 \\
\hline 14 & $66.26^{\mathrm{a}}$ & 5.83 & 43.07 \\
\hline 21 & $67.30^{\mathrm{a}}$ & 5.99 & 46.60 \\
\hline \multirow[t]{2}{*}{28} & $65.40^{\mathrm{a}}$ & 5.14 & 47.07 \\
\hline & $\mathrm{P}<0.05$ & $\mathrm{P}<0.01$ & $\mathrm{P}<0.01$ \\
\hline \multicolumn{4}{|c|}{ Packing $(\mathrm{P})$} \\
\hline $1-$ vacuum & $67.51^{\mathrm{a}}$ & 5.46 & 44.93 \\
\hline $2-$ seq. $\mathrm{O}_{2}$ & $66.11^{\mathrm{a}}$ & 5.88 & 45.02 \\
\hline $3-$ seq. $\mathrm{O}_{2} / \mathrm{CO}_{2}$ & $65.53^{\mathrm{a}}$ & 5.83 & 45.07 \\
\hline \multirow[t]{2}{*}{$4-$ seq. $\mathrm{O}_{2}$ ger. $\mathrm{CO}_{2}$} & $65.47^{\mathrm{a}}$ & 5.53 & 42.51 \\
\hline & $\mathrm{P}<0.05$ & $\mathrm{P}<0.01$ & $\mathrm{P}<0.01$ \\
\hline Int. T x P & NS & $\mathrm{P}<0.01$ & $\mathrm{P}<0.01$ \\
\hline CV $(\%)$ & 2.49 & 3.99 & 2.59 \\
\hline
\end{tabular}

a,b Means followed by the same letter at the column do not differ by Tukey test $(\mathrm{P}<0.05) ; \mathrm{CV}=$ coefficient of variation; NS $=$ nonsignificant. $\mathrm{O}_{2}=$ oxygen; $\mathrm{CO}_{2}=$ carbon dioxide.

Table 4 - Values of $a^{*}$ and $b^{*}$ to each vacuum packaging system at different storage time.

\begin{tabular}{lcccc}
\hline \multirow{2}{*}{ Packing $(\mathrm{P})$} & \multicolumn{4}{c}{ Storage time in days $(\mathrm{T})-$ Value of a* } \\
\cline { 2 - 5 } & 7 & 14 & 21 & 28 \\
\hline $1-$ vacuum & $6.15^{\text {ax }}$ & $5.71^{\text {ax }}$ & $5.54^{\text {bx }}$ & $4.43^{\text {by }}$ \\
$2-$ seq. $\mathrm{O}_{2}$ & $5.77^{\text {aby }}$ & $5.89^{\text {ax }}$ & $6.48^{\text {ax }}$ & $5.39^{\text {axy }}$ \\
$3-$ seq. $\mathrm{O}_{2} / \mathrm{CO}_{2}$ & $5.75^{\text {abx }}$ & $6.18^{\text {ax }}$ & $5.88^{\text {abx }}$ & $5.52^{\text {ax }}$ \\
$4-$ seq. $\mathrm{O}_{2} /{\text { ger. } \mathrm{CO}_{2}}$ & $5.30^{\text {by }}$ & $5.53^{\text {axy }}$ & $6.06^{\text {abx }}$ & $5.22^{\text {ay }}$ \\
\hline Package $(\mathrm{P})$ & 7 & Storage time in days $(\mathrm{T})-$ Value of $\mathrm{b}^{*}$ \\
\hline $1-$ vacuum & $42.70^{\text {ay }}$ & $42.93^{\text {ay }}$ & $47.64^{\text {ax }}$ & $46.45^{\text {bx }}$ \\
$2-$ seq. $\mathrm{O}_{2}$ & $41.12^{\text {ay }}$ & $43.60^{\text {ax }}$ & $47.06^{\text {ax }}$ & $48.30^{\text {abx }}$ \\
$3-$ seq. $\mathrm{O}_{2} / \mathrm{CO}_{2}$ & $39.62^{\text {az }}$ & $44.32^{\text {ay }}$ & $46.30^{\text {ay }}$ & $50.05^{\text {ax }}$ \\
$4-$ seq. $\mathrm{O}_{2} /$ ger. $\mathrm{CO}_{2}$ & $39.72^{\text {ay }}$ & $41.44^{\text {ay }}$ & $45.41^{\text {ax }}$ & $43.49^{\text {bx }}$ \\
\hline
\end{tabular}

a,b Means followed by the same letter (column) do not differ by Tukey test $(\mathrm{P}<0.05) ;{ }^{\mathrm{x}, y, z}$ Means followed by the same letter (line) do not differ by Tukey test $(\mathrm{P}<0.05) ; \mathrm{O}_{2}=$ oxygen; $\mathrm{CO}_{2}=$ carbon dioxide; $\mathrm{a}^{*}=$ redness; $\mathrm{b}^{*}=$ yellow intensity. 


\section{CONCLUSIONS}

The vacuum in the packings analyzed is responsible for the internal quality of the eggs. In addition, the preservation of the internal quality of these eggs is more evident when they are stored in cases with $\mathrm{O}_{2}$ absorbent and $\mathrm{CO}_{2}$ producer.

\section{ACKNOWLEDGEMENTS}

This study received financial support from the Fundação de Apoio à Pesquisa do Estado de São Paulo (FAPESP), Brazil.

\section{REFERENCES}

ANTUNES, R. Avicultura industrial 2001. Available in: http://www.aviculturaindustrial.com.br. Accessed Jun 2012.

CARD, L. E.; NESHEIM, M. C. Produción avícola. Zaragoza: Editoral Acribia. 1978.

FRANCO, J. R. G; SAKAMOTO, M. I. Qualidade dos ovos: uma visão geral dos fatores que a influenciam. 2007. AveWorld. Available in: http://www.aveworld. com.br. Accessed Jun 2012.

FREITAS, L. W. et al. Aspectos qualitativos de ovos comerciais submetidos a diferentes condições de armazenamento. Agrarian. 4: 66-72, 2011.

HAUGH, R. R. The Haugh unit for measuring egg quality. US Egg and Poultry Magazine. 43:552-555, 1937.

JONES, D. R.; MUSGROVE, M. T. Effects of extended storage on egg quality factors. Poultry Science. 84:1774-1777, 2005.
KAROUI, R.; NICOLAÏ, B.; BAERDEMAEKER, J. Monitoring the egg freshness during storage under modified atmosphere by fluorescence spectroscopy. Food Bioprocess Technology. 1:346$356,2008$.

LEANDRO, N. S. M. et al. Aspectos de qualidade interna e externa de ovos comercializados em diferentes estabelecimentos na região de Goiânia. Ciência Animal Brasileira. 6:71-78, 2005.

OGDEN, I. D. et al. Produção e embalamento de ovos controle da qualidade e segurança em cadeias de produção biológica. 2005. Research Institute of Organic Agriculture FiBL. Available in: http://www. orgprints.org. Acessed Jun 2012.

SANTOS, M. S. V. et al. Efeito da temperatura e estocagem em ovos. Ciência e Tecnologia de Alimentos. 29:513-517, 2009.

SCATOLINI-SILVA, A. M. et al. Physical qualitative of stored eggs in different packing condition on room temperature. Archivos de Zootecnia. 62(238):248, 2010.

THERON, H. P. et al. Bacterial growth on chicken eggs in various storage environments. Food Research International. 36:969-975, 2003.

UNITED STATE DEPARTMENT OF AGRICULTUREUSDA. Egg-Grading Manual. Washington:

Departament of Agriculture. 56p. 2000. 